\title{
Public or private administration of justice: privatization of prisons
}

Anders Løvlie, professor, University of Oslo, Department of Public and International Law Papuna Guruli, invited lecturer, St. Andrew the First-Called Georgian University of the Patriarchate of Georgia, Attorney at Law, General Specialization.

\begin{abstract} several value judgments and empirical assumptions. og verdimessige premisser for spørsmålet om privatisering.

\section{Keywords}

prisons, privatization, crime prevention

fengsler, Kriminalomsorgen, privatisering, kriminalitetsforebygging
\end{abstract}

This article concerns the privatization of prisons and its consequences for the weakening of the state's monopoly on punishment. It presents an analytical overview of arguments for and against the privatization of prisons in the light of recent developments in Norway. It concludes that the arguments are complex and interwoven and that they rest on

Artikkelen omhandler privatisering av fengsler. Det redegjøres for enkelte generelle trekk ved privatisering av fengsler og fremheves forhold som indikerer at privatisering kan bli aktuelt i Norge. Formålet med artikkelen er å gi en analytisk fremstilling av argumentene for og mot privatisering av fengsler, herunder løfte frem relevante empiriske

\section{Introduction}

This article is concerned with questions that arise in case of privatizations of prisons and the consequences if the state's monopoly on the use of punishment is weakened. ${ }^{1}$ It contributes to the international debate on prisons as institutions by presenting an analytical overview over arguments for and against privatization of prisons. The topic is relevant from a Nordic perspective, due to some recent tendencies towards privatization in Norway.

1. The article is based on a presentation held 12.03.20 - the day before Corona shutdown - at the seminar Nordic Punishment at a Crossroads?, arranged by The punishment, penology and criminal law research group at the Faculty of Law, University of Oslo. We would like to thank the organizers, research fellow Bård Sverre Tuseth and the two anonymous referees. 
In section 2, we first show that the use of prisons follows from general principles concerning the justification for punishment, we also give a brief overview of the use of private prisons. In section 3 we address some trends which shows that the question of privatization is relevant for Norway. In section 4 we present various arguments for and against privatization. Section 5 provides a summary of the findings.

The main purpose of the article is to systemize relevant arguments from the debate on privatization of prisons and to present the arguments within a theoretical analytical framework. Our approach is norm descriptive as we identify both legal and moral arguments from legal texts and the scholarly and public debate. We have limited our self to an eclectic search in the mentioned sources, and do not summarize or review existing literature or analyze the public and private prison industry.

\section{Private prisons}

In Western jurisdictions the use of punishment is traditionally justified both as retribution and as a tool for social policy. The first line of reasoning relies on criminal liability being reasonable and just. The second line of reasoning relies on assumptions concerning the benefits of punishment, including assumptions about how the threat of punishment prevents criminal acts (Roxin, Arzt, Tiedemann, pp. 4-7). Imprisonment is one of several different forms of punishment.

A state can be defined and understood as an institution with monopoly on the use of violence, with imprisonment as an extreme representation of the state's sovereign prerogative. A division can be drawn between public driven and privatized prisons, out from which is in charge and has the responsibility for guarding, security and content. Privatization is in this sense a broad concept that implies that an entity other than the state itself is engaged by the government to run the prisons, with aims varying from idealistic to profit making.

This division is not a dichotomy as prisons also can be semi-private in the sense that guarding and security is operated by the State, and non-coercive activities such as kitchen service, laundry, and maintenance are outsourced. It is quite common also for public prisons to have some services handled by private companies. Hence privatization of prisons can be more and less extensive also with regard to the level of state supervision.

The use of private prisons has increased in the world since the 1980s, and it seems to have a high level of support in countries of common law although it is less popular in countries of civil law (White, p. 134). The percentage of privatized prisons in the USA is around eight (Sawyer and Wagner; The Sentencing Project), and around $15 \%$ in United Kingdom (Nowak, p. 122). Semi-private prisons you find for example in France (Nowak, p. 128). The increase of the private prison sector is explained partly as a result of overcrowding and partly 
as a result of retributive justice ideology taking over for ideas of rehabilitation, and effectiveness (Dolovich, p. 439-440; Nowak, p. 120-121).

The question of private prisons is highly dynamic and there are continuous discussions as to whether to increase or decrease its use. This is illustrated by the fact that it affected the stock prices for the country's two largest prison companies when Joe Biden was elected as president of the US in 2020 as he had pledged during his campaign to end the federal government's use of private prisons (Pauly), which was followed up on January $26^{\text {th }} 2021$ when President Biden sent out the following tweet: "No one should be profiteering off of our criminal justice system. That's why today, I ordered the Department of Justice to end the use of private prisons by the federal government" (Biden 2021). Other examples are that United Kingdom recently placed a large private prison under permanent public sector control due to low prison standards (HM Chief Inspector of Prisons 2018; HM Chief Inspector of Prisons 2019; UK Parliament House of Commons 2019), and that Germany abolished the use of semi-private prisons in 2014 (Nowak, p. 128).

\section{Trends in Norway}

The Nordic countries have a long and strong tradition of public prisons, but there are some recent tendencies that indicates that the private privatization of this sector may play a larger role in years to come. In the following this will be illustrated with three examples from Norway, but discussions about privatization are also found in other Nordic countries, for example Denmark (Rådet for Offentlig-Privat Samarbejde).

This is not to say anything about representativeness, even though it seems reasonable as a hypothesis that the case of Norway could be to a certain degree representative for nearby countries, as there are similarities within other parts of the prison system. The Nordic countries are to great extent based on the same ideological principles, and there has been an extensive cooperation and exchange of ideas within the criminal justice systems. Similarities are often clear from a distance, for example the American scholar UN Special Rapporteur on Torture 2004-2010 Manfred Nowak writes on rehabilitation:

This simple logic is underlined by the empirical fact that countries with the highest standard of prison conditions, such as the Nordic countries in Europe, usually also have the lowest recidivism, crime and incarceration rates (Nowak, p. 136).

When we systemize the arguments for and against privatization in section 4 our focus is the distinction between private and public prisons in its purest form. When we in the following point to tendencies towards privatization in Norway we however also point to private features within public prisons. Partly because these are in themselves exceptions from the state's sovereign prerogative and might be indicators for a state's potential and willingness to 
privatize, and partly because some of the arguments for privatization are of relevance to such features, for example there are legal regulations on government procurement and the obligation to issue public tenders that opens a potential shift between traditionally idealistic service providers such as The Red Cross or The Salvation Army and private profit oriented entities.

The Norwegian Correctional Service has the responsibility for and run all prisons, and according to the so-called import model other crucial services are delivered to the prison by other government agencies, such as medical, educational, or library services: "The cooperation shall contribute to a coordinated effort to cover the needs of convicted persons and inmates and to promote their return to society" (The Execution of Sentences Act section 4).

However, there is also a long and strong tradition of some services from private actors. For example, the prison authorities have over years from the Salvation Army acquired housing services where around thirty detainees train for living and work. In addition, the state budget has of 2020 a specific post for private organizations with a direct funding of 25 million NOK and funding through the Norwegian Correctional Service of 2 million NOK (Justis- og beredskapsdepartmentet 2020, p. 13). These are not large numbers, but in a budget which is lowered in recent years they are not insignificant either.

A first indication which imply more use of private actors in the future was the statement by the Government in 2013 that they wanted to: "Increase the use of voluntary and non-profit organizations in the criminal justice system, both during imprisonment and when returning to society" (Political platform). Also the harsh critique of the use of isolation during pretrial and sentencing, is from The Norwegian Correctional Service partly met by an initiative that invite private persons and institutions to apply for funding:

An important challenge for the prison authorities is that many inmates spend a large part of the day alone on their own cell. There is a need to strengthen the services offered to inmates who for various reasons feel "isolated". KDI wants to prioritize cooperation with organizations that will make an effort in this are (Kriminalomsorgsdirektoratet). ${ }^{2}$

Secondly there has recently been privatization in the sense that a prison has been administered by another state. The government concluded that there was a need to increase prison capacity and in 2015, Norway's Parliament (Stortinget) amended the Execution of Sentences Act by adopting a new Section 1a, which provided legal authority for transferring inmates to serve their sentences in another state with which Norway has entered into an agreement, it is stated that a convicted person who serves a sentence in another state

2 "En viktig utfordring for kriminalomsorgen er at mange innsatte tilbringer en stor del av døgnet alene på egen celle. Det er behov for å styrke tilbudet til innsatte som av ulike grunner opplever å være 'isolert'. KDI ønsker å prioritere samarbeidet med organisasjoner som vil gjøre en innsats på dette område". Our translation. 
"is considered to be imprisoned in Norway and shall [ ... ] have the rights and obligations arising from this" (The Execution of Sentences Act section 1a).

In 2015 the parliament also consented to an Agreement with the Netherlands on renting places at Norgerhaven Prison for the execution of sentences for persons convicted of criminal offences in Norway. This was a fully equipped prison with Dutch personnel and administrative staff. The prison had a capacity of 242 inmates and was operated from September 2015 until August 2018. It was stipulated that the execution of the sentence shall be regulated by Norwegian legislation and subject to Norwegian administration, and it was managed by a prison governor and a deputy prison governor, both of whom are Norwegian. However, The Agreement between Norway and the Netherlands stated that the receiving State shall provide "the staff necessary to implement the cooperation agreement" and that transport on Dutch territory to and from the prison must be carried out by Dutch officers and that Dutch instructions for the use of force in prison applied (Kingdom of Norway and the Kingdom of the Netherlands).

Thirdly privatization is on the political agenda and there are political initiatives that signals privatization. The Norwegian Progress Party (Fremskrittspartiet) is a libertarian right-wing political party. The party was a part of a center-right government coalition from 2013 until it withdrew in January 2020. During their time in government, they had the Minister of Justice. Their Party Manifesto stated: "The Progress Party wants to abolish the queue for imprisonment. This can be done [ ... ] by allowing private actors to build and own prisons on behalf of the state" (Fremskrittspartiet, p. 51). ${ }^{3}$ And it also says: "The Norwegian Progress Party wants to buy prisons cells abroad" (Fremskrittspartiet, p. 51). ${ }^{4}$ These proposals are considered serious and have been discussed and criticized by the labor movement (Håkonsen 2016a). There are also companies with interest in a private prison marked that has stated that they could provide necessary services on very short notice (Kjernli E.).

\section{Arguments for and against privatization}

\subsection{Introduction}

In the following we address the question whether the authority to deprive a person of their freedom in order to enforce criminal law should be handled exclusively by the state, or whether this authority could be delegated to a private enterprise. This question has been debated within different jurisdictions (Field; Robbins; White, pp. 134-145; Dolovich; Henry). One can identify four lines of reasoning that will be elaborated on in the following, institutional

3 "Fremskrittspartiet vil holde soningskøene nede. Dette kan blant annet gjøres ved å la private aktører bygge og eie fengsler på oppdrag fra staten". Our translation.

4 "Fremskrittspartiet vil [...] kjøpe soningsplasser i utlandet". Our translation. 
arguments (section 4.2), human-rights arguments (section 4.3), arguments of utility (section 4.4) and arguments of jurisdiction (section 4.5).

\subsection{Institutional arguments}

The essence of the institutional argument is that prisons belong to the core of a state's sovereign function. It rests on modern political philosophy and the idea that states are obliged to protect both personal security and public order, often advocated with reference to The Rule of Law. The premise is that generally formulated norms which constraint individual and institutional behavior, for example principles of generality, universality and separation of powers, only will be effective within a legal and political transparent entity:

The idea of freedom from sovereignty that the rule of law claims, requires that the sovereign have definite limits, that when an institution or person acts, we can know clearly if it or she is the sovereign. Who, otherwise, is to be restrained from whom? It is in this manner that rule of law norms presuppose the clear segregation of state from civil and domestic society and of public from private realms (White, p. 119).

A formal expression of this idea is to be found in the Grundgesetz für die Bundesrepublik Deutschland article 33 (4), that rules that exercise of sovereign authority on a regular basis shall "be entrusted to members of the public service who stand in a relationship of service and loyalty defined by public law." The Federal Constitutional Court of Germany has concluded that derogations from this principle should be limited to exceptional cases and only when it is justified by an objective reason (Bundesverfassungsgericht, paragraph 144-146). The court has made it clear that prison sentencing is an essential part of the state functions:

The implementation of detentions imposed under criminal law belongs to the core functions of sovereign power. In that respect, there is no relevant difference, be it in view of the intensity of potential interferences with fundamental rights or otherwise, between forensic treatment and the execution of prison sentences [ ... ]. In such a context, a person endowed with coercive powers in its interactions with inmates exercises a sovereign function even if in most cases - precisely because of these powers - he or she does not have to issue official orders or use direct force to implement them (Bundesverfassungsgericht, paragraph 153).

Private prisons violate the constitutional non-delegation doctrine and is prohibited under the Grundgesetz, which probably also will be the case under Austrian law (Nowak, p. 130). However, this does not categorically exclude the possibility of exceptions if there are very good reasons for such an arrangement. In the case referred above the court accepted a privately run psychiatric prison, but the company was owned by the state and was not operating for profit. The reason for privatization was to maintain the organizational cooperation between forensic and other psychiatric facilities. Thus, there was state supervision of the practice, and other safeguards as well (Bundesverfassungsgericht, paragraph 155 following). 


\subsection{Human rights arguments}

Human rights are moral principles or norms that describe certain standards of human behavior, and with reference to national and international law it has been argued that private prisons are not compatible with human rights obligations. Obviously, a state can't avoid its constitutional or international obligations by delegating state functions to private actors, the question is whether the obligations limit the possibility to use private actors. One can distinguish between different aspects of the argument, as it relates to A) human dignity, B) specific human rights for prisoners or C) the potential for human rights violations.

Ad A: The concept of human dignity is based on a recognition of human beings possessing a value intrinsic to being human and as such should be respected. There are states that guarantee for the citizen's human dignity in their constitutions, which can shed light over how the argument unfolds. Israel Supreme Court has ruled that the use of private prisons will violate the right to "human dignity" (The Supreme Court of Israel). The government of Israel wanted to establish a prison operated and managed by a private corporation, but the Supreme Court held with a majority vote that it would be a disproportionately intervention in the right to human dignity and therefore unconstitutional (The Supreme Court of Israel, paragraph 36 to 39). The premises rested on three aspects: First that the desire of the private corporation operating the prison to make a financial profit turns the prisoners into a means to an end; reflects a lack of respect for the status of the inmates as human beings (The Supreme Court of Israel, paragraph 28). Secondly the invasive character of the powers that the private concessionaire and its employees are to exercise. Thirdly the symbolic significance of imprisonment in a privately managed prison will have.

Ad B: In the debate on privatizations of prisons one may find arguments referring to specific human rights, however they are seldom specified. Several international conventions contain rights that protect prisoners, for example the International Covenant on Civil and Political Rights article $10 \mathrm{nr} .3$ states "The penitentiary system shall comprise treatment of prisoners the essential aim of which shall be their reformation and social rehabilitation." This and similar obligations on restorative justice does not in itself prohibit the use of private companies but might limit to what extent a state can regulate sentencing out of purely economic motives when sentencing.

Ad C: All modern states guarantee for Humans rights both in national and according to international law and thereby have a so-called positive obligation to protect their citizens from Human Rights violations. It has been argued that the use of private prisons increases the risk of Human rights violations, for example, the UN Human Rights Committee has stated their concern about whether the use of private prisons in New Zeeland challenges obligations under the Human Rights: 
[I]t [ ... ] remains concerned about whether the practice of privatization, in an area where the State is responsible for protecting the rights of persons whom it has deprived of their liberty, effectively meets the obligations of the State party under the Covenant and its own accountability for any violations (Human Rights Committee).

Whether or not there is an actual risk is an empirical question. Some empirical studies indicate that the risk for violations can be higher in private than in public prisons. For example, it has been reported to be more violence in private prisons than in public prisons in England and Wales (Grierson J. and Duncan P.).

\subsection{Arguments of utility}

The utility arguments address whether and to what extent the purpose of punishment can be secured with private prisons, and therefore depends on the reasons for the use of punishment. It emphasizes that the question of public vs. private administration of justice first and foremost needs to be discussed and analyzed through the prism of criminal law as it gives the premises for the use of punishment (Guruli 2020).

The use of punishment is, as stated in section 2, justified partly as retribution and partly as a tool for social policy. The first line of reasoning relies on criminal liability being reasonable and just, and the second relies on assumptions concerning the benefits of punishment, including assumptions about how the threat of punishment (general prevention) and positive influence over the prisoner during the imprisonment (special prevention) helps to prevent criminal acts. In Norway the use of punishment is primarily justified by the second line of reasoning, and as pointed out in section 4.3 the states are obliged to secure reformation and social rehabilitation according to the International Covenant on Civil and Political Rights article $10 \mathrm{nr} .3$.

The utility arguments used in favor of private prisons are that they are effective and less costly and innovative (Rådet for Offentlig-Privat Samarbejde), and that they provide a practical solution to intermediate problems such as overcrowding. One example of this line of reasoning is the following statement from a spokesman for the Norwegian Progress Party discussing privatization with the labor movement:

Competition usually results in cheaper and better operation. If you have two who come up with an offer, you get a completely different dynamic [ ... ] It is a condition that others who run prisons or prison transport do so under given conditions. There must be no hocus pocus. We have already opened up the monopoly to voluntary actors like the Salvation Army (Håkonsen 2016b). ${ }^{5}$

5. "Konkurranse gir som regel en billigere og bedre drift. Har du to som kommer med et tilbud, får du en helt annen dynamikk [...] Det er en forutsetning at andre som skal drive fengsler eller fangetransport gjør det under gitte premisser. Det må ikke være noe hokus pokus. Vi har allerede åpnet opp monopolet til frivillige aktører som Frelsesarmeen." Our translation. 
Arguments of utility used against private prisons seems to presuppose that there is an inherent contradiction between the quality of services of any kind and the private contractors' financial self-interests or profit motive (Henry, p. 198-199), in addition to an increased risk for corruption and limited responsibility and control. For example, there has been argued that the private prison industry has no interest in decreasing recidivism as that would undermine business (Guruli 2020). The strength of such arguments will depend on the contractor's incentives and criteria for evaluation defined by the government and whether and to what extend the ends are controlled (Ministry of Justice United Kingdom).

The utility arguments are to some extent derived from more general perspectives and views on which role the government should have regulating and guiding market economies. This might also explain the growth of private prisons, as the privatization seems to be more extensive in countries that are generally thought to be marked oriented economy and with an ideology that limit state intervention in the marked.

One must then also take into account macro perspectives such as globalization and formal binding economic models for the states. The states obligation on public procurement might for example affect what until now has been a stable relationship between the government and some private actors, such as cooperation between the prison authorities and idealistic organizations, since the procuring authority are legally obliged to issue public tenders to secure marked competition when the value of the procurement exceeds a certain threshold, and this might result in commercial actors outcompeting the idealistic organizations providing services for the prisons.

\subsection{Arguments related to jurisdictions}

Private prisons are sometimes located in a different jurisdiction than the contracting state, either between national states or between different jurisdictions under a federal state, and such arrangements might give rise to legal uncertainty regarding the control over the imprisoned person and the sentencings content. Hence this argument addresses how jurisdiction has an effect on the A) institutional, B) human rights and C) utility arguments (Nerbø).

Ad A: When Norway executed sentences in the Netherlands from 2015-2018, it was unsuccessfully argued for the High Court that it was a breach of The Norwegian Constitution article 106 which states: "Norwegian citizens may not be refused entry into the realm" (Borgarting). The case shows that sentencing abroad at least touches upon some underlying institutional values. It was not brought in for the Supreme Court apparently due to lack of relevance.

Ad B: The Norwegian Parliamentary Ombudsman, who has a mandate to prevent human rights violations, visited and evaluated the Dutch prison. The conclusion was that the inmates weren't guaranteed adequate protection from the Norwegian authorities, as they lacked the possibility to investigate, 
prosecute and punish violations of the prohibition against torture and other cruel, inhuman or degrading treatment or punishment:

\begin{abstract}
In certain situations, another state's authorities are permitted use of coercive measures, including weapons, against inmates who have been convicted in Norway. From a preventative point of view, a solution of this kind, in which the Norwegian authorities are prevented from fulfilling their responsibility to protect inmates, entails a risk of torture and ill-treatment (Sivilombudsmannen 2016). ${ }^{6}$
\end{abstract}

Ad C: The use of a Dutch prison has also been criticized for being incompatible with the purpose of the sentence as a restorative process, as it limits the possibilities for measures that are likely to counteract new criminality, such as going on leave and receiving visitors (Nerbø). The Ombudsman also found that The Norwegian authorities did not conduct a satisfactory review of how the medical rights of the inmates were safeguarded by Dutch health legislation.

\title{
5. Conclusion
}

The arguments for and against the use of private prisons are complex and rest on several value judgments and empirical assumptions. It is therefore important, for a start, to make clear the goals of imprisonment and consider under which system, if any, or combination of systems, the goals are best reached. In the present article we have not intended to take a stand in the discussion of whether or not prisons should be operated by private entities, but we have highlighted arguments anyone with an interest should take in consideration. This might be necessary also in the Nordic countries, at least in Norway we have seen a political and practical positive attitude towards privatizing within the prison system. To sum up one might say that Norway is at a crossroads, understood partly normative-descriptively as a meeting place between different institutional ideas, partly as a distinct change of practice, and partly normatively as a point in time and space where decisions on further practice must be taken.

Kontaktoplysninger

Anders Løvlie: anders.lovlie@jus.uio.no

Papuna Guruli: papunaguruli@gmail.com

6. For the following discusion see Justis- og beredskapsdepartementet (2017) and Sivilombudsmannen (2017). 


\section{References:}

Biden J. (2021). No one should [ ... ].@POTUS, US government account, The White House. 27.01.21, 12.00 a.m (Norwegian time). Available at: https://twitter.com/POTUS/status/1354202467483975680 (Accessed 27.01.21)

Borgarting lagmannsrett (2016). Dom og kjennelse [Borgarting High Court - Judgement and ruling] 29.06.16 (LB-2016-31801 - LB-2016-31800 - LB-2016-31782 - LB-2016-31796).

Bundesverfassungsgericht (2012). Judgement in Mr S [ ... ] against the order of the Frankfurt/ Main Higher Regional Court [ ... ] 18.01.12. BvR 133/10 English translation. Available at: https://www.bundesverfassungsgericht.de/SharedDocs/Entscheidungen/EN/2012/01/ rs20120118_2bvr013310en.html (Accessed 30.12.20).

Dolovich S. (2005) State Punishment and Private Prisons. Duke Law Journal Vol. 55 nr. 3 pp. 437-546. Available at:

https://scholarship.law.duke.edu/cgi/viewcontent.cgi?article=1274\&context=dlj (Accessed 30.12.20).

Field J.E. (1987). Making Prisons Private: An Improper Delegation of a Governmental Power. Hofstra Law Review Vol. 15 pp. 649-675. Available at:

https://scholarlycommons.law.hofstra.edu/cgi/viewcontent.cgi?article=1600\&context $=h \mid r$ (Accessed 30.12.20).

Fremskrittspartiet (2017). Prinsipp- og handlingsprogram (Plan of action) 2017-2021. Available at:

http://flippage.impleoweb.no/frp/b8188708c47948288727ef8f91683698/FRP-Program2017-2021.pdf\#page=1 (Accessed 30.12.20).

Grierson J. and Duncan P. (2019). Private jails more violent than public ones, data analysis shows. The Guardian 13.05.19 (online). Available at:

https://www.theguardian.com/society/2019/may/13/private-jails-more-violent-than-public-prisons-england-wales-data-analysis (Accessed 30.12.20).

Guruli P. (2020). Idea of private prisons - Through the prism of goals of punishment. Law and World Issue nr. 142020 pp. 78-82. Available at:

https://lawandworld.ge/en/articles/idea-of-private-prisons-through-the-prism-of-goalsof-punishment/ (Accessed 30.12.20).

https://doi.org/10.36475/14.1.7

Henry F.B. (2019). Private Prisons \& Human Rights: Examining Israel's Ban on Private Prisons in a U.S. Context. Concordia Law Review 20194 (1) pp. 198-212. Available at https://www.ncbi.nlm.nih.gov/pmc/articles/PMC6781874/ (Accessed 30.12.20).

HM Chief Inspector of Prisons (2019) Report on an independent review of progress at HMP Birmingham of 18.06.19. Available at:

https://www.justiceinspectorates.gov.uk/hmiprisons/wp-content/uploads/sites/4/ 2019/06/Birmingham-IRP-web-2019.pdf (Accessed 30.12.20).

HM Chief Inspector of Prisons (2018) Urgent Notification: HM Prison Birmingham of 16.08.18. Available at:

https://www.justiceinspectorates.gov.uk/hmiprisons/wp-content/uploads/sites/4/ 2018/08/16-Aug-UN-letter-HMP-Birmingham-Final.pdf (Accessed 30.12.20).

Human Rights Committee (2002). Report 2002 Volume I, A/57/40. Available at: https://www.refworld.org/docid/3f475d7e2.html (Accessed 30.12.20).

Håkonsen D.K. (2016a). Frp vil privatisere kriminalomsorgen. Fri Fagbevegelse 28.09.16 (online). Available at:

https://frifagbevegelse.no/nffmagasinet/frp-vil-privatisere-kriminalomsorgen6.158.411783.c4aba73118 (Accessed 30.12.20)

Håkonsen D.K. (2016b). Kari Henriksen (Arbeiderpartiet) avviser privat drift av fengsler: - Private fengsler gir mer vold og kriminalitet. Fri Fagbevegelse 29.09.16 (online). Available at:

https://frifagbevegelse.no/nffmagasinet/-private-fengsler-gir-mer-vold-og-kriminalitet6.158.412265.335018f6ae (Accessed 24.02.20). 
Justis- og beredskapsdepartementet (2017). Oppfølging av Sivilombudsmannens besøksrapport fra Norgerhaven fengsel, 01.06.17. Available at:

https://www.regjeringen.no/contentassets/31cd6e5c3e964e56b619d7d460c8f3a6/oppfolging-av-sivilombudsmannens-besoksrapport-fra-norgerhaven-fengsel.pdf (Accessed 30.12.20).

Justis- og beredskapsdepartmentet (2020). Tildelingsbrev [Letter of allocation] 2020 Kriminalomsorgsdirektoratet 23.01.20. Available at

https://www.regjeringen.no/contentassets/b04b5cf8bb32490c990a82fd90fa05a0/tildelingsbrev-2020-kdi.pdf (Accessed 30.12.20).

Kingdom of Norway and the Kingdom of the Netherlands (2015) Agreement between the Kingdom of Norway and the Kingdom of the Netherlands on the use of a prison in the Netherlands for the purpose of the execution of Norwegian sentences of imprisonment 02.03.15. See

http://www.kriminalomsorgen.no/traktatnnorge-nederland-pdf.5822011-356410.html (Accessed 30.12.20).

Kjernli E. (2015). Private aktører er klare til å bygge fengsler. Norsk Rikskringkasting 23.07.15 (online). Available at:

https://www.nrk.no/norge/private-aktorer-er-klare-til-a-bygge-fengsler-1.12467450 (Accessed 30.12.20).

Kriminalomsorgsdirektoratet (2019). Tilskudd til frivillige og ideelle organisasjoner [Grants to volunteers and ideal organizations]. Available at:

https://www.kriminalomsorgen.no/tilskudd-til-frivillige-og-ideelle-organisasjoner. 6185502-237613.html (Accessed 30.12.20).

Ministry of Justice United Kingdom (2020). Annual Prison Performance Ratings 2019/20. Official Statistics Bulletin Ministry of Justice (UK), 30.07.20. Available at:

https://assets.publishing.service.gov.uk/government/uploads/system/uploads/attachment_data/file/913004/annual-prison-performance-ratings-2019-20-bulletin.pdf (Accessed 30.12.20).

Nerbø H.K (2017). Norgerhaven fengsel - et sjansespill med innsattes rettssikkerhet og rehabilitering. Kritisk juss nr. 32017 pp. 145-149. Available at:

https://www.idunn.no/kritisk_juss/2017/03/norgerhaven_fengsel (Accessed 30.12.20). https://doi.org/10.18261/issn.2387-4546-2017-03-03

Nowak, M (2016) Human Rights or Global Capitalism - The Limits of Privatization. University of Pennsylvania Press.

https://doi.org/10.9783/9780812293494

Pauly M. (2020). Private Prison Stocks Drop as the Reality of Biden's Win Sinks In. Mother Jones 09.11.20 (online). Available at

https://www.motherjones.com/crime-justice/2020/11/private-prison-biden-stocks/ (Accessed 30.12.20).

Political platform (2013). Political platform for a government formed by the Conservative Party and the Progress Party, Sundvolden 7th October 2013. Available at: https://www.regjeringen.no/contentassets/a93b067d9b604c5a82bd3b5590096f74/poli tisk_platform_eng.pdf (Accessed 30.12.20).

Robbins I.P. (1988). The Impact of the Delegation Doctrine on Prison Privatization. University of California Law Review Vol. 351988 pp. 911--952. Available at:

https://papers.ssrn.com/sol3/papers.cfm?abstract_id=2789715 (Accessed 30.12.20).

Roxin, Arzt, Tiedemann (2013). Einführung in das Strafrecht und Strafprozessrecht. 6 Auflage. C. F. Müller.

Rådet for Offentlig-Privat Samarbejde (2013) Muligheder og potentialer for at skabe konkurrence om fængselsdrift. Retsudvalget 2012-13 Alm. del Bilag 321. Available at: https://www.ft.dk/samling/20121/almdel/reu/bilag/321/1259983.pdf (Accessed 30.12.20). 
Sawyer W. and Wagner P. Prison (2020) Mass Incarceration: The Whole Pie. Policy Initiative 24.03.20 (online). Available at:

https://www.prisonpolicy.org/reports/pie2020.html (Accessed 30.12.20).

Sivilombudsmannen (2016). Visit report Norgerhaven Prison 19-22 September 2016 (English). Available at:

https://www.sivilombudsmannen.no/wp-content/uploads/2017/05/2016-Norgerhavenprison-Visit-report-EN.pdf (Accessed 30.12.20).

Sivilombudsmannen (2017). Svar på oppfølging av Sivilombudsmannens besøksrapport fra Norgerhaven fengsel 28.09.17. Available at:

https://www.sivilombudsmannen.no/wp-content/uploads/2017/03/SOMs-svarbrev.pdf (Accessed 30.12.20).

Straffegjennomføringsloven (2001) (Act relating to the execution of sentences etc. - The Execution of Sentences Act). Available at https://lovdata.no/dokument/NLE/lov/2001-05-18-21 (Accessed 30.12.20).

The Sentencing Project (2019). Private prisons in the United States. The Sentencing Project 24.10.19 (online). Available at:

https://www.sentencingproject.org/publications/private-prisons-united-states/ (Accessed 30.12.20).

The Supreme Court of Israel sitting as the High Court of Justice (2009). Judgment in Academic Center of Law and Business, Human Rights Division et al. vs. Minister of Finance et al. 19.11.09. HCJ 2605/05. Available at:

https://versa.cardozo.yu.edu/sites/default/files/upload/opinions/Academic\%20Center\% 20of\%20Law\%20and\%20Business\%20v.\%20Minister\%20of\%20Finance.pdf (Accessed 30.12.20).

UK Parliament House of Commons (2019) Prisons and Probation debated 14.05.19. Hansard Volume 660. Available at:

https://hansard.parliament.uk/Commons/2019-05-14/debates/1F4E18A1-F260-4F82888D-59FEDD63E3C5/PrisonsAndProbation (Accessed 30.12.20).

White, A.A. (2001) Rule of Law and Limits of Sovereignty: The Private Prison in Jurisprudential Perspective. American Criminal Law Review Vol. 38: 111 pp. 111-146. Available at: https://scholar.law.colorado.edu/cgi/viewcontent.cgi?article=1592\&context=articles (Accessed 30.12.20). 